\title{
Romans and Romantics
}

\author{
Ed. Timothy Saunders, Charles Martindale, \\ Ralph Pite, and Mathilde Skoie. \\ Oxford: Oxford University Press, 2012. \\ $x x i i+431$ p. $£ 89.00$
}

The narration of literary history, as we know it, has a number of recurring characteristics, including the ideas of succession and evolutionary lineages. Epochs are supposed to be clearly and mutually delimited and also to simultaneously emerge from, and to negate, each other. The rhetorical power of epochal narration stems from a construction favouring diametrical oppositions. Arranged in this way, the literary heritage becomes manageable, understandable, and teachable. The evolutionary organisation of knowledge is usually traced back to the roots of modern literary historiography in Romanticism; yet, it has become increasingly apparent that models of this sort have repeatedly hindered what may seem more adequate descriptions of Romanticism. A flagrant example of this is a common view of Romantic writers and classical heritage as antithetical. Already the designation of the new literature as 'Romantic' implied the idea that while classicism drew its inspiration from classical literature, Romantic authors turned to medieval literature. The circumstance that several key Romantics were prominent classical scholars, and could even picture the approaching literary era as a rebirth of classical an- tiquity, has in this perspective been a paradoxical fact.

Thus it is highly welcome that in recent years we have seen an increasing number of studies modifying or, more often, completely overturning the idea of anti-classical Romanticism. As the Greek heritage has typically been in focus, though, this idea has sometimes been replaced by the idea of anti-Roman Romanticism. The anthology Romans and Romantics thus recompenses for a double neglect. The aim of the anthology is twofold: to highlight the significance of Roman antiquity for Romanticism, and to demonstrate how the idea of ancient Rome is subsequently filtered through the Romantic image of it. The volume forms part of the OxfordSeries Classical Presences, which in no less than 54 volumes so far (2005-June 2013) is devoted to the reception of classical antiquity.

Romans and Romantics is a rich and rewarding book. In particular its first part opens up new perspectives: Jonathan Sachs illuminates the importance of Rome in relation to British Romanticism; Helge Jordheim discusses the 'struggle with time' in Jean Paul's novel Titan (180o-1804); Timothy Saunders scrutinizes the 
concept of originality in relation to ideas of Rome in, among others, Johann Joachim Winckelmann and the Schlegel brothers; Mathilde Skoie accounts for Romantic readings of the elegies of Roman authoress Sulpicia; and Genevieve Liveley studies Romantic reception of Ovid in her discussion of the concept of 'love'.

In the second part of the volume we find readings of individual Romantic authors: Stuart Gillespie and Bruce Graver devote one essay each to William Wordsworth; Juan Christian Pellicer discusses Charlotte Smith; Catharine Edwards analyses Germaine de Staël's Corinne (1807); Timothy Webb elaborates on Lord Byron's, Mary Shelley's, and Percy Bysshe Shelley's reactions to contemporary and ancient Rome; Jostein Børtnes writes about Alexander Pushkin's relationship to Ovidian exile; Jørgen Magnus Sejersted's article concerns Henrik Wergeland's Skabelsen, Mennesket og Messias (1830); and Carl J. Richard discusses American Romanticism (Ralph Waldo Emerson and Nathaniel Hawthorne).

Part III of the anthology, finally, deals with the reception of the Romantic notion of Rome: Elizabeth Prettejohn explores the novel The Amazon (1880) by Carel Vosmaer; Stefano Evangelista deals with Walter Pater's novel Marius the Epicurean (1885), Ralph Pite discusses Thomas Hardy, especially his 'Poems of Pilgrimage' (1902); Erling Sandmo examines Romantic opera; and Piero Garofalo, finally, considers Rome and Romanticism in Italian cinema. The eighteen articles are surrounded by excellent pro- and epilogues by Ralph Pite and Glenn W. Most, respectively.

The conception of Greece as the great novelty of the time and a favourite object of Romantic desire is hardly challenged by the contributors. Greece undoubtedly exerted a deep attraction over the Romantics, whether they, led by Winckelmann, wished to rediscover Greek art, or, driven by national or religious pathos, supported the Greek struggle for independence. But the fact that Greece was still exotic and difficult to access, while Rome had long belonged to the grand tour of educated youth, along with the situation that school teaching was dominated by Latin, while the knowledge of Greek was often poor, makes it evident that the importance of Rome should definitely not be underestimated. As several of the contributors attest, Greece and Rome were not conflicting entities for Romantic authors; on the contrary, the notion of Greece was more often than not filtered through Rome, just as Winckelmann had based much of his seminal ideas of Greek art on Roman copies.

A central suggestion in Sachs's article - elaborated in his book Romantic Antiquity: Rome in the British Imagination 1789-1832 (2010) - is that republican Rome after 1789 became politically combustible material in British Romanticism. Thus it could also offer models for the perception of modernity: 'Republican Rome, in this reading, becomes increasingly influential in the Romantic period because in a period of political unrest, imperial expansion, and aesthetic reformation, Rome provided competing allegories 
for sensitive issues surrounding these aspects of modernity in contemporary Britain' (25). In a general sense Sachs's suggestion is valid for several of the readings in the volume. Jordheim depicts the way the passive and apathetic traveller in Jean Paul's Titan through his visit in Rome is transformed into a 'glowing revolutionary' (51), and Erling Sandmo claims that even the relative absence of Roman motives in Romantic opera can be explained by the conception of classical and especially Roman history as revolutionary and thus awkward for the ruling elite (350).

Very illuminating is Timothy Saunders' investigation of the concept of originality, habitually associated so intimately with the Romantic period that it is sometimes regarded as its constituting moment. Saunders, though, goes ad fontes and reveals a different picture. The veneration of originality is as we know fully developed in the epoch preceding Romanticism; one need only mention Edward Young's Conjectures on Original Composition (1759). The Romantics, however, are rather ambivalent on the issue. Friedrich Schlegel distinguishes between different kinds of imitation: autonomous imitation concerning 'the universal spirit' and slavish, 'simple imitation of the particular' (70). Only the latter, he claims, is reprehensible. The view on the Romantics as promoters of a natural primitivism cannot hold true, either. In the Romantic version of this theme, inherited from the eighteenth century, poetry is instead perceived as an interaction between the 'natural' and the 'artificial' (76).
The declared aim is to offer, 'for the first time, an extensive and wideranging discussion of the relationship between Romanticism and Roman antiquity'. Undoubtedly, the totality of the volume is rich and varied, with great diversity in space and time. Perhaps, however, the purpose would have benefited from a concentration around the core issues; the breadth of subjects, not least the volume's extension in historical time, comes at the expense of depth. German Romanticism, despite the fruitful contributions in the first part of the volume, may seem somewhat neglected, while other parts of European Romanticism stay terra incognita. For names such as François René de Chateaubriand or Alphonse de Lamartine we look in vain, and investigations into areas such as Romantic drama or Romantic art could certainly have deepened the discussion.

Such objections, however, only point to the richness of the field and should not obscure the fact that Romans and Romantics is a highly recommendable and eye-opening book. The last word is hardly said about the relation between Romanticism and Roman antiquity, but this volume makes obvious the potential and productivity of the subject.

Paula Henrikson Research fellow at the Swedish Academy, supported by a grant from the Knut and Alice Wallenberg Foundation, appointed at Uppsala University 